\title{
TO THE PROBLEM OF THE I (Language Games: Whether the Sum Equals Zero?) ${ }^{1}$
}

\section{V.P. ZINCHENKO}

And while nurturing an uncreated world, $I$ forgot the unnecessary $I$. O. Mandelstam

I am alone, while all is submerged in hypocrisy, Living righteously is not an easy walk in the park.

B. Pasternak

Man, Personality, Persona, Subject, Individual, and the I make twice as much as those three pines among which psychology wanders. This 'hexahedron' opens up even a greater scope for language games than the 'triangle' of Subject, Individual and Personality. But I would like to simplify the situation. First, I will dwell on Personality (which I am going to lose very quickly on my way), and then I will focus on the $I$.

"Shares of the individual in history are falling", said O. Mandelstam in 1922 when writing the article "The End of a Novel." Ten years later, the poet, in response to the onset of "the spider web of deafness" (while standing at the edge of a "failure" that is "stronger than our strength"), wrote:

If all the living is only a correction Over a short and lifeless day,
The final step on Lamarck's moving stairs Will I take.

In the same years, B. Pasternak, watching real life, said about this in a more straightforward way but not less strongly:

Personalities cannot even be considered. The matter should immediately be dropped.

After a few decades, Vladimir Vysotsky wrote the famous lines:

There are few real violent ones,

Therefore there are no leaders.

Long before these poets, Pavel Florensky wrote about the impossibility to define Personality. He only noted that Personality was a limit of SelfConstruction, or Self-Creation. Echoing

${ }^{1}$ Translated from: Zinchenko, V. P. (2012). To the problem of the I (Language Games: Whether the Sum Equals Zero?). In V. N. Porus (Ed.), The problem of "I": philosophical traditions and modernity (pp. 157-194), Moscow: Alfa-M. Translated and published with a permission of the publishing house «Tsentr gumanitarnykh initsiativ». Poetry is translated by E. Gaevskaya и D. Vonsboro. 
Florensky, Aleksei Losev stated that Personality was a myth, a miracle, and a mystery. Psychologists did not heed the warnings of wise poets and philosophers, and decided to take on Personality by direct attack. Firstly, they took advantage of Marx's definition of Man as "the sum of all social relationships" but they substituted Personality for Man. However, other than Lev Rubinstein they failed to notice that according to Marx social relations themselves are constructed from individual relationships. The dissolution of Personality in social relations was not enough. It was dropped below Individual by putting the latter above Personality, and finally they equalized the former with the Subject (the Subjectness of an Individual, Personality Subject, etc.), i.e. with the Sub-ject, with the Subject's characteristics. It is fair to say that M. Bakhtin, L. Bozovic, and A. Leontiev stressed the crucial role of Action in the formation of Personality.

The demagoguery concerning the establishment of Personality in a group has not been in vain: Personality is a product (or a by-product) of a group of people. Today, Personality is drowning not only in hypocrisy but also in consumption or through fantasies about it. Few people remember that Personality is the basis of a group.

The $I$ is undergoing a similar (though not as sad) fate. Once exaggerated statements like "I am the state", "the Super-Ego", "The Throne I" (Marina Tsvetaeva), "I am the creator of my own worlds" (Mandelstam), are identified with either the Subject or the Object, or are propagated vegetatively, or, like Personality, get dissolved in various relationships: "I am the world, "I am you", "I am the other", "I am us", "I am them", "The Cumulative I", "The Collective I", "I am the second I', etc. Thanks to M. Buber, G. Shpet, M. Bakhtin, D. Elkonin, and F. Gorbov the relations that the $I$ is involved in, unlike just "public relations", are yet concretized and personified, and most importantly a hyphen (or a dash) signifies a living productive (and sometimes fatal) space between, in which the $I$ is born and must bear the burden of functions (which are not in the least secondary). Creative (author's) generating capacities and functions are typical for the $I$. At times the $I$ even thinks, and is not just "a parasite on the body of the subjectless thought" (Shchedrovitskii). Such capabilities and features are hidden behind metaphors of the $I$ that is indeed many-sided: "The Swarmy I" (Proust), "The Multiple I-ity" (Bibler), "Mono-multitude of the Is", etc. Metaphors, according to Pasternak, are shorthand for the great personality, a cursive script of its spirit; but a metaphor does not replace or supersede the task of decrypting Personality, identifying and analyzing the structure of its phenomenon. Psychologists and psychotherapists have partly proved to be powerless in deciphering or building the structure of $I$. They shift the problem of the $I$ onto the shoulders of those within their care (their patients and subjects of trials), inviting them to come up with their own "Concepts of the $I$ " on the way. Psychoanalysts are much more aware of the immense complexity of the structure of the Ego than psychologists are. The main difficulty in the analysis of the Ego is that it (like, indeed, many other elements of psyche) exists not only in its observed outward form but also in an inward virtual form, which is no less efficient. 
We shall refer to the experience and thoughts of psychoanalysts. At first they considered the $I$ as a psychic instance, then later as a main instance or a substructure of Personality. However, a broader structure, if any, was left out of their attention and analysis, as they obviously considered Personality a taken for granted phenomenon of everyday life'. Taking a bit of a leap, dare I say that psychoanalysts have likewise neglected the concept of individuality? The concept of the $I$ turned out to be primal and self-sufficient for the psychopathology of everyday life. Freud likened the $I$ to a real organ (a functional one, I should add). This organ, despite all failures, is in principle capable (being a representative of reality) of gradually mastering instincts. Moreover, Freud compared the $I$ to an organism, "the simplest living creature", and believed that the modification of the $I$ is like a bodily lesion in tissues. Following Freud's considerations, Jean Laplanche and J.B. Pontalis saw the $I$ as a kind of an embodied metaphor for the body as a whole (2010, p. 656). Initially, in the year 1922, Freud characterized the "body" of the $I$ quite naturalistically saying that the $I$ was first and foremost something corporeal: it is not only a superficial formation but also a projection of a certain surface. Then he made a note to this statement explaining that ultimately the $I$ arises from bodily sensations, mainly from those that are born on the surface of a body. Hence, the $I$ can also be seen as a mental surface of the mental apparatus (Ibid., p. 664). Here the I clearly appears as an external form of either the body or the mental apparatus. We shall talk of its completion later. And now we shall note that comparing psyche to organs, the organism and its tissues, is nothing new. A. Ukhtomskiy defined functional organs as any temporary combination of forces that is capable of realizing a certain achievement. He emphasized the importance of "the health-enhancing regenerating tissue of consciousness." He also spoke of the spiritual body. The latter is constructed from functional organs that possess biodynamic, sensual, emotional and social tissues. N. Bernstein believed movement to be a living being that was reactive, sensitive, evolving and involuting. These same properties are typical for the $I$. Ukhtomskiy considered not only movement, but also the image, and the psychological recollection, and attention, and functional status, and even personality as functional organs, that is, as a combination of forces. Is it possible that the forces are drawn from a reserve, the primary energy reservoir (that is carried by the $I d$, in accordance with Freud)? In the logic of Freud, this assumption is reasonable, though not certain. The $I d$ is a subjectless chaos that has its origins (and energy) in biological needs. It gradually breaks up, and the $I$ and even the Super-Ego are formed based on it. There are other opinions on the sources of energy: eidetic energy, the energy of knowledge and error, the energy of the soul and spirit, etc. Freud did not confine to the energetic characteristics of $I d$. After all,

${ }^{1}$ Sigmund Freud used to consider even great personalities at a level as low as that of his neurotic patients. 
energies differ. And Freud used his own topology (tiered) system of consciousness (consciousness, preconscious, unconscious) to build the topology of the $I$ system: Super-Ego, I, Id, giving to each of the levels their own, however, amorphous, functions and energy. It turns out that the $I$ system, like other mental systems (such as perception, attention, memory, thinking) has a large number of excessive degrees of freedom. And to make the $I$ capable at the right moment it is necessary to overcome this excess, especially the chaos of the $I d$, and to save only those that ensure the implementation of the act required. For example, to fulfill a reasonable action it is necessary to overcome the drives and passions of $I d$, and to overcome the resistance, inhibition and censorship of the Super-Ego. Then the released the $I$ ceases (temporarily) to be the holder, or the owner, of a virtual set of actions, as it itself becomes an action or an act: I am all attention, I am all observation; I am all tension, I am all will. Or I am all feeling, I am all passion:

$<\ldots>$ For I myself am

Love. For I myself am the surface! J. Brodsky

Indeed, the $I$ can fit into a sick tooth like into a tight boot. Then, according to A. Bely, psychology densifies into physiology. Shortly before his death, Freud suffering from a terminal illness wrote to Marie Bonaparte: "My world has again turned into a small island of pain afloat in the ocean of indifference."

The picture drawn is certainly an oversimplification. In fact, the overcoming of incredibly redundant relationships of the I towards (real, imaginary, fictitious) reality and transform- ing them into real relations (relations in reality) often represent a drama and sometimes even a tragedy. Psychoanalysts give examples of the neurotic Ego remaining defenseless, on the one hand, under the pressure from the ruthless Id, and, on the other hand, under the pressure of not less merciless SuperEgo (Strachey, 2000, pp. 88-89). The author writes that both pressures form a vicious circle and prevent a fullfledged contact of the Ego with reality. Concerning Freud's triad one can't help recalling the Swan, the Crayfish and the Pike in the fable by I. Krylov.

Freud and his followers mention (in addition to the three-tier $I$ system) a large number of the $I$ 's varieties that are not all distributed in the system levels: "I the Ideal", "The Ideal $I$ ", " $I$ the Libido", "I the Observer", "I the Observed", "I the Pleasure", "I the Reality", "I the Instinct”, "I the Love", "I the Interest", "I the Mediator", "I the Object", "I the Narcissus", etc. This is the result of the $I$ 's dismembering and a group of ideas about it and about the heterogeneous instinctive drives and feelings inherent to it, and this is not surprising as Freud pointed out the heteronomy of the $I$, its dependence on other mental instances and on the outside world. Here we are faced with a paradox partly mentioned above. We naively believe that the $I$ is the master of our spirit and body organization. However, the omnipotence of our $I$ is in the distant past - in infancy, and it refers rather not to the $I$ but to the proto- $I$. I mean the omnipotence of a baby described by D. Winnicott who generates the sensations of Eden (or Hades). And this omnipotence is the baby's illusion, which is however, very useful for his or her further develop- 
ment. In fact the adult $I$, according to Freud, is "the servant of three masters" that is at risk from three sides (the outside world, the libidinal impulses of the Id and the severe Super-Ego). Sometimes it certainly manages to overcome the threats coming from different sides and becomes the master of the situation.

The interaction between two topological structures - the consciousness of the $I$ and the $I$ - remains unclear. On the one hand, Freud described consciousness not as an independent system but as "the core I." Preconscious functions are passed on to the $I$. However, on the other hand, Freud insisted on the fact that the $I$ was mainly an unconscious instance, hence there is a special effort required to become aware of it. I think that this contradiction is constructive. An extended concept of reflection as an essential property of consciousness is necessary to overcome it. The recent studies have shown that in the subject action (as well as in other acts where the $I$ "dissolves") there is an unconscious background reflection (Gordeeva \& Zinchenko, 2001). V. Lefebvre wrote about the reflection in mental acts that is rapid and also unconscious (1990). A. Pyatigorskiy introduced the concept of "the reflection without the $I$ " (2002). Although Pyatigorskiy called the concept of "reflexion" (we shall read it as "reflex-and-I") the Z reflex, therefore having stripped it of the $I$, this is not the reflex in the Pavlovian sense of the word. We can assume that the $I$ will not dissolve in the acts mentioned above ("I am all...") but it becomes their internal form while being a carrier of consciousness, and keeps it as its own nucleus.
However, it is the core, which is not easier to understand than the nuclear one, because it can explode in the form of a deed. Psychologists and psychoanalysts have been studying its structure for many years. Whatever the structure of consciousness, it is important to emphasize that it can be regarded as an internal form of the $I$. If this assumption is correct then it is not the unconscious $I$ but the $I$ that has consciousness that powerfully influences behavior and activity (at the same time the $I$ may not be aware of the fortune (or misfortune) of such possession). The fact that consciousness may not be within the scope of awareness does not deprive it of its efficiency. This statement should not be surprising. We do not always realize that the inner form of the word is comprised of the image and the action; the inner form of the action is the image and the word; finally, the inner form of the image is made of the action and the word. It is about the expansion of our understanding of the internal forms. It is hard to say whether they exist in parallel rows, or if they fit into each other and have a "matryoshka doll" structure. In the logic of Freud the $I$ is a part of perception, attention is a part of action, and consciousness (the nucleus!) is a part of the $I$. This is proved by Freud's widely used terminology (such terms as "internalization", "introjection", "intellectualization," as if taken by him from a thesaurus of cultural-historical psychology). Freud spoke about the historical implications of mental acts. Psychoanalysis can not only be interpreted on the basis of cultural and historical grounds, but many of its ideas have been ahead of cultural-historical psychology and enrich it. 
Let us return to the unconscious possession of consciousness. It is this consciousness that is "released" (or "breaks out") with an act. M. Mamardashvili was certainly right in saying that the problem of the unconscious is above all a problem of consciousness. Today it is no longer necessary to prove that only creatures that have consciousness also possess the unconscious.

We should consider another very important question about the origin of the $I$, which was not set aside by psychoanalysts. Freud was initially approaching the $I$ in a way "from below". The $I d$ is older than the $I$. The $I$ has developed from it like a cortical layer under the influence of the outside world. Later a specific area is separated within the $I-$ the area of the SuperEgo. Then Freud recognized that the $I$ was not the result of the progressive differentiation of psyche. For the $I$ to occur a new mental action is needed. The $I$ is neither a product of the $I d$, nor simply the result of its splitting followed by autonomization. The abovecited Laplanche and Pontalis write that the " $I$ is not so much an apparatus formed on the basis of the system of Perception-Consciousness but an internal form generated by a number of especially significant perceptions - not only of the outside world in general but of the world of intersubjective relations" (2010, p. 664). The $I$ is not automatically established. Psychoanalysts describe the specific mental operations of borrowing features, images and forms from another person: (self-)identification, introjection, narcissism, the "good" object - the "bad" object, etc. The specifics of identification have been those most studied in detail. It causes profound changes in the $I$ turning it into an intra-subject residue of inter-subject relations (Ibid., p. 659). Incidentally, it is such a "residue" that can fill all the "space" (we use the Freudian topology here) of the $I$. The genuine $I$ is rather an excess of intersubjective relationships: the $I$ 's own contribution to the formation of the own I (please forgive the tautology that is useful for understanding). N. Berdyaev (who said that in his $I$ there is more of others than of himself) apparently underestimated himself. It is important to emphasize that psychoanalysts overcome the Freudian naturalism and contribute to the understanding of the above-mentioned living space between where the most important events of human life take place.

Thus, psychoanalysts are groping for their ways "from above" that have already been thought through and drawn by philosophers and psychologists. I shall remind us of what $M$. Buber wrote: a subtle space of the personal $I$, which requires to be filled with another $I$, is formed in the plane of the $I-$ Thou. This idea is also expressed in an old paper by G. Shpet: the $I$ itself (like the unity of many other "unities of consciousness") is a group and an assembly (2006, p. 306). In the logic of B. Elkonin the $I-$ Thou initially acts as a combined $I$, being an agent, or an actor, of the "cumulative action" and of the "merged communication" (Shpet's terms). In this logic the $I$ becomes autonomous not from the $I d$ but from the $I-$ Thou. If we accept this logic, then inevitably the question arises, whether the Id is necessary in the structure of the $I$. There is a Freud's well known saying: "Where the $I d$ was, there the $I$ shall appear.” After all, we 
are in an internal conversation, sometimes in an argument not with the $I d$, but with our second $I$, and we do not always know which of the Is - the first or second one - will be the winner. The Super-Ego cannot help in this conversation or dispute either. If the $I d$ is present, the conversation would be idle, and the $I$ would submit to the authority of the Super-Ego. It is only possible that the authoritative Other will act as a Super-Ego, although of course the former is not omnipotent. In my opinion, the scheme or structure of the $I$ - the second $I$ (that was discussed in detail by F. Gorbov) is self-sufficient. It is truly cultural and historical, rather than naturalistic. I should remind of the "anti-naturalistic protest" of Boris Pasternak: "Well, what are you? <..> What is it about you that you have always known as yourself? What are you conscious of in yourself? Your kidneys? Your liver? Your blood vessels? No. However far back you go in your memory, it is always in some external, active manifestation of yourself that you come across your identity-in the work of your hands, in your family, in other people. $<\ldots>$ You in others-this is your soul. $<\ldots>$ You have always been in others and you will remain in others. And what does it matter to you if later on that is called your memory? This will be you-the you that enters the future and becomes a part of it." If the word "You" is replaced with the word "I", this will be cultural-historical psychology of the $I$.

Above, rather, in the subtext than in the text there was an intention expressed to compare psychological approaches to personality and psychoanalytic approaches to the $I$. I shall make two common (yet without argument) comments on this. 1. In psychology we deal with the personality (but is it the personality at all?) without the $I$. In psychoanalysis we deal with the $I$ but without the personality. 2. Both psychologists and psychoanalysts tend to reduce the $I$ to the individual, to the subject, to the representative, or to the body. Freud is excusable as he was involved in the psychopathology of everyday life and did not claim to establish the language of psychology and only wrote "The Project for a Scientific Psychology" (1895). He could afford to consider the Oedipus complex as a basis for structuring the personality. (Our ideologues prefer to see such a framework in patriotism.) Psychologists seem concerned rather with the zone (or the prospect of) the nearest and more distant human development (or do they just pretend to care?), and they should break out beyond the ordinary and not forget about the way "from the top" or "to the top."

Here is a wise statement by Osip Mandelstam:

What allies us, only the superfluous, before us - not the failure, but an error in the measure... ${ }^{3}$

This statement is consistent with ideas of the soul as a mysterious abundance of knowledge, feelings, and will; with ideas of the $I$ as an excess of human relations and of the personality

${ }^{2}$ B. Pasternak (1958). Doctor Zhivago. New York, New York: Pantheon Books, Inc. Translated by Max Hayward and Manya Harari.

${ }^{3}$ Translated by Raina Kostova. 
as an excess of the same relations and own individuality.

In all three examples it is a question of overcoming degrees of freedom that are natural, excessive and not created by us, and of constructing (creating) our own cultural excess of degrees of freedom: the space of the internal excess (Mandelstam). Again this is topology, or chronotope, of the conscious and unconscious life in the way Freud, A. Ukhtomskiy, N. Bernstein, M. Bakhtin, L. Vygotsky, K. Lewin, and M. Mamardashvili would treat it.

In conclusion I should say that I have failed to lose the personality in this discussion. Apparently, it was prevented because of my longing for the personality whose shares have fallen not only in history but also in the human sciences. Freud lowered the personality to the level of the ordinary, often reducing it up to a not too certain $I$ with all of its divisions, dismemberment and levels. In turn, psychologists, together with sociologists and philosophers, have lowered it to the subject: to the function or to the collection of functions. But there is not only science but also practice that either is in the footsteps of science or paves the way for it. Freud is normally praised for the fact that neuroses, complexes, etc. theoretically designed by him have penetrated into life and damaged not only the individual but also the social tissue, and hallmarked the culture of the XX Century. In the same century an event happened that had a not lesser but greater significance. Social mythology, or rather, delusions that had been produced either by N. Chernyshevsky, or Trotsky, or M. Gorky about the formation of a "new man", came true. And such a man has become a reality. A. Platonov described him as a man without soul and property who stands in the waiting room of history ready for anything but for his own past. Here the practice has closed (is closing?!) the way of science but it has opened the way for dissertators to write and defend a myriad of dissertations about phantom problems of personality formation.

What do we get as a result of language games? The result is in favour of psychoanalysis. The practice of peeking into oneself that psychoanalysis (following poetry) teaches us is much better than the practice of forming, testing, and manipulating the personality. We can call the former case excessive, and the latter - unprofitable. But I will yet finish with an optimistic note. Contrary to psychology and psychoanalysis, there are total persons who have not a dismembered but a whole $I$. And if the earth is still turning, it is only because they do exist.

\section{References}

Gorbov, F. (2000). Ya - vtoroye Ya [The I - the Second I]. Moscow/Voronezh: NPO "MODEK".

Gordeeva, N.D., \& Zinchenko, V.P. (2001). Rol' refleksii v postroienii predmetnogo deistviya [The role of reflection in the construction of subject's action]. Chelovek. 6, 26-41.

Laplanche, J., \& Pontalis, J.-B. (2010). Slovar' po psikhoanalysu [The dictionary of psychoanalysis]. Saint Petersburg: The Center for Humanitarian Initiatives. (Transl. of: Laplanche, J., \& Pontalis, 
J.-B. (1967). Vocabulaire de la psychanalyse [The language of psychoanalysis]. Paris: Presses Universitaires de France. (in French))

Lefebvre, V. (1990). Nepostizhimaya effektivnost' matematiki v issledovanii refleksii [Inconceivable effectiveness of mathematics in study of reflection]. Voprosy Filosofii, 7.

Pyatigorskiy, A. (2002). Myshlenie i nabludenie [Thinking and observation]. Riga: Liepnieks \& Ritups. Shpet, G. (2006). Philosophia Natalis. Izbrannye psikhologo-pedagogicheskie trudy [Philosophia Natalis. Selected psychological and pedagogical works]. Moscow: ROSSPEN.

Strachey, J. (2000). Kharakter psikhoterapevticheskoy raboty v psikhoanalyse [The nature of psychotherapeutic action in psychoanalysis]. In A. V. Rossokhin (Ed.), Antologiya sozremennogo psikhoanaliza [Anthology of modern psychoanalysis] (Vol. 1, pp. 81-107). Moscow: Institute of Psychology of Russian Academy of Sciences.

Zinchenko, V. (2011). Bluzhdanie v tryokh sosnakh, ili Toska po lichnosti [Wandering in broad daylight, or Longing for personality]. Chelovek, 4, 5-20.

Работа печатается по изданию: Зинченко, В. П. (2012). Проблема Я и другие тайны (Языковые игры: не с нулевой ли суммой?). В кн. В. Н. Порус (ред.), Проблема «Я»: философские традиции и современность (с. 157-194). М.: Альфа-М.

Перевод и публикащия материалов производились с разрешения ЦГИ Принт. 